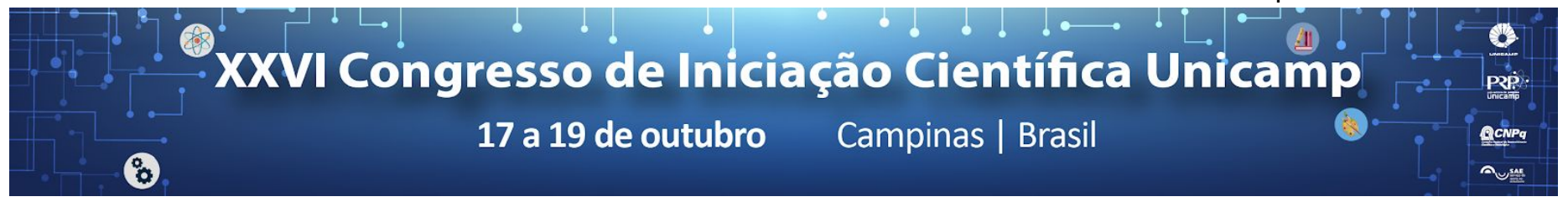

\title{
Nanoestruturação de nanofolhas de óxido de grafeno reduzido com glicose oxidase (GOx) para verificar transferência direta de elétrons.
}

\section{Igor Carneiro Figueredo*, Antonio Riul Junior.}

\section{Resumo}

A nanoestruturação de materiais possibilita explorar propriedades únicas não observadas em macroescala, e uma técnica bastante explorada é a de automontagem por adsorção física (LbL ,do inglês Layer by Layer). Neste trabalho fizemos filmes LbL de óxido de reduzido ( $\mathrm{rGO}$, do inglês reduced graphene oxide) funcionalizado com polialilamanina hidroclorada (PAH) e poliestirenossulfonado (PSS), que denominaremos respectivamente de GPAH e GPSS. A ideia inicial era a nanoestruturação de filmes (GPAH/GPSS) com a enzima glicose oxidase, seguido da caracterização eletroquímica dos filmes formados.

\section{Palavras-chave:}

Nanoestruturação, Layer by Layer, rGo.

\section{Introdução}

Pelo elevado potencial de aplicação tecnológicas como em biossensores e biocélulas combustíveis o rGO junto com a técnica LbL [1] tem sido bastante estudados [2]. Neste projeto, utilizamos nanofolhas de rGO funcionalizadas com $\mathrm{PAH}$ e PSS, dando origem aos compostos GPAH e GPSS, respectivamente, de modo a formar suspensões aquosas estáveis que possibilitem a aplicação da técnica LbL. Em trabalhos futuros pretendemos imobilizar a GOx entre as nanofolhas de GPAH e GPSS de maneira a captar elétrons liberados pela atividade enzimática.

\section{Resultados e Discussão}

Pelo elevado potencial de aplicação tecnológicas como em biossensores e biocélulas combustíveis o rGO junto com a técnica LbL [1] tem sido bastante estudados [2]. Neste projeto, utilizamos nanofolhas de rGO funcionalizadas com PAH e PSS, dando origem aos compostos GPAH e GPSS, respectivamente, de modo a formar suspensões aquosas estáveis que possibilitem a aplicação da técnica LbL. Em trabalhos futuros pretendemos imobilizar a GOx entre as nanofolhas de GPAH e GPSS de maneira a captar elétrons liberados pela atividade enzimática.

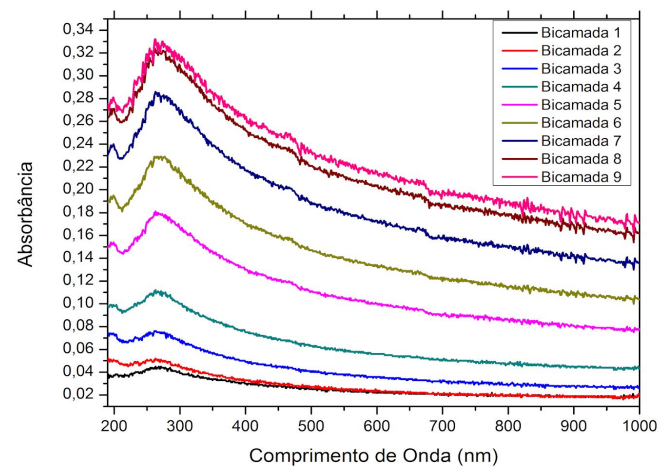

Figura 1. Absorção UV-Vis adquirida em cada bicamada depositada.

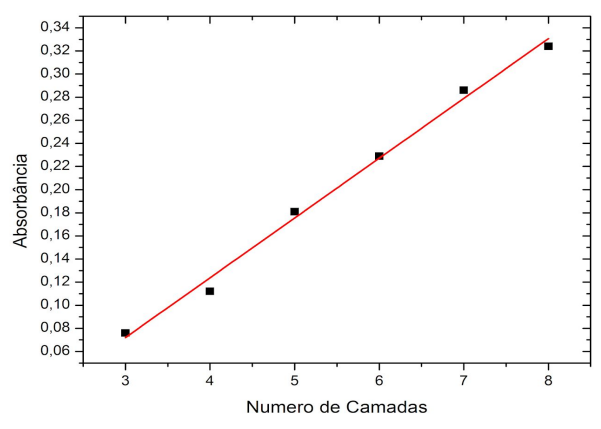

Figura 2. Ajuste linear dos valores máximo de absorbância para cada bicamada.

\section{Conclusões}

Através da caracterização UV-Vis foi possível mostrar que a aplicação da técnica de LbL com rGO na arquitetura molecular (GPAH/GPSS) foi bem executada. Houve linearidade durante o crescimento, mostrando que uma mesma quantidade de material foi transferida em cada etapa de deposição.

\section{Agradecimentos}

Gostaria de agradecer ao meu orientador Antonio Riul Jr. pelo apoio ao longo do desenvolvimento do trabalho. Agradecer também ao meu co-orientador Varlei Rodrigues e o grupo de pesquisa pelo suporte.

\section{G. Decher, Science (80 ), $1997,277,1232-1237$.}

G. R. J. Heather R.Luckarift, Plamen Atanassov, Ed.,Enzymatic Fuel Cells: from fundamentals to applications, Wiley-VCH Verlag GmbH \& Co. KGaA, New Jersey, 1st edn. 2014. 